Asian J. Med. Biol. Res. 2018, 4 (1), 69-76; doi: 10.3329/ajmbr.v4i1.36824

\author{
Asian Journal of \\ Medical and Biological Research \\ ISSN 2411-4472 (Print) 2412-5571 (Online) \\ www.ebupress.com/journal/ajmbr
}

Article

\title{
Assessment of fish diversity and socio-economic condition of fishermen in Bangladesh
}

Md. Ishtiaque Jahan ${ }^{1}$, Mohammad Shafiqul Alam ${ }^{1}$, Md. Shamsul Karim ${ }^{2}$, Nargis Sultana ${ }^{1}$, Md. Mamun ${ }^{1}$ and S.M. Rafiquzzaman ${ }^{1}$ *

${ }^{1}$ Department of Fisheries Biology and Aquatic Environment, Faculty of Fisheries, Bangabandhu Sheikh Mujibur Rahman Agricultural University, Gazipur, Bangladesh

${ }^{2}$ Senior Upazilla Fisheries Officer, Dept. of Fisheries, Bangladesh

${ }^{*}$ Corresponding author: S.M. Rafiquzzaman, Associate Professor, Dept. of Fisheries Biology and Aquatic Environment, Faculty of Fisheries, Bangabandhu Sheikh Mujibur Rahman Agricultural University, Gazipur, Bangladesh. Phone: +8801754041311; E-mail: rafiquzzaman@ bsmrau.edu.bd

Received: 05 March 2018/Accepted: 20 March 2018/ Published: 29 March 2018

\begin{abstract}
The main objectives of the study were to determine the present status of fish biodiversity and socioeconomic condition of fishermen in Belai beel during February 2016 to September 2016 by survey method using questionnaires, field visit and interviewing with the fishermen. The results indicated that about 27 species of fish fauna were found in the Belai beel, among them 23 species were indigenous and 4 species were exotic. Major dominant species were Rui (Labeo rohita), Catla (Catla catla), Bata (Labeo bata), Shingi (Heteropeneustes fossilis), Magur (Clarius batrachus), Tengra (Mystus tengra), Chanda (Chanda nama), Kakila (Xenentodon cancila), Common carp (Cyprinus carpio), Mola (Amblypharyngodon mola) in the study area. During the study period two critically endangered (Puntius sarana, Pangasius pangasius), two endangered (Labeo bata, Channa marulius), and three vulnerable (Chanda nama, Channa orientalis, Notopterus notopterus) fish species were found in the Belai beel. Analysis of socio-economic condition of fishermen showed that maximum (70\%) had nuclear family and others $(30 \%)$ had joint family, as well as fishermen, belonged to the age groups of 31 to 40 years (50\%) and the others were 15 to 30 (20\%), 41 to 50 (18\%), 51 to 60 (10\%), 61 to 70 $(2 \%)$. Overall, the present study suggested that fishermen communities should be educated by creating awareness for the proper conservation, management, and enhancement of biodiversity in the Belaibeel.
\end{abstract}

Keywords: fish diversity; socioeconomic condition; Belai beel

\section{Introduction}

Assessment of fish biodiversity of freshwater resources and socioeconomic condition of fishermen has become a pressing issue for fisheries scientists, fisheries managers, ecologists, environmentalists. The freshwater fisheries resources of Bangladesh are declining day by day due to lack of proper management policy, over-exploitation and the unplanned establishment of dams (FAO, 2009). Moreover, the rapid growth of population and high rate expansion of agricultural activities, unplanned industrial activities are major threats for the freshwater fisheries resources.

The freshwater bodies of Bangladesh are considered a home to at least 265 species of fin fishes (Rahman, 2005).The haors, baors, beels, and jheels are of fluvial origin and are commonly identified as freshwater resources (DoF, 2015). Beel is generally rich in fisheries resources. Once, this beel had abundant of native wild fish species, prawn, snail, crabs and turtles. Due to over exploitation and various ecological changes of the beel, some important fish species and turtles have disappeared. The Belaibeel is rich in fisheries resources. Considering the fertility and nutrients, overall ecosystem of the Belaibeel is productive and is inhabited by 
diversified fauna. The abundance of small native fishes has been declined due to overfishing and deterioration of natural habitat.

Freshwater resources play an important role in the socio-economic development of the country. Recently, this sector is providing opportunities for economic as well as social upliftment. Fisheries sector has already been well-known as a vital income and employment-generating sector in Bangladesh, cheap sources of healthy food for the population of the country. Fish supplements to about $60 \%$ of our daily animal protein intake. More than $11 \%$ of the population is dependent directly and indirectly on the fisheries for their living (DoF, 2015).

Owing to massive loss in aquatic biodiversity of freshwater resources, a well-planned and systematic study is required to assess the present status of biodiversity in the Belaibeel of Bangladesh with a view to take an appropriate action to preserve and manage the aquatic fauna. The present study focuses on the abundance, species combination, and related aspects of the Belaibeel. Many fishermen are involved in this beel for their livelihoods. No research has been done before in this beel. The present research was conducted to determine the fish biodiversity, and socio-economic conditions of the fishermen of the Belaibeel at Gazipur district in Bangladesh.

\section{Materials and Methods}

\subsection{Study area and period}

The area of Belai beel is about $8 \mathrm{sq} \mathrm{km}$ with an average depth of $9 \mathrm{ft}$ which is located at Kaliganj upazilla of Gazipur district (Figure 1). This study was conducted from February 2016 to September 2016.

\subsection{Collection of data}

Data were collected by using two methods: (a) Questionnaire survey (b) Physical observation. Data was collected by personal interviews through questionnaire. Forty fishermen were selected through random sampling. The primary data were assembled through field survey at the village level by using a well structural questionnaire. Data were collected both by physically observation and interview with fishermen at house, field, fishing place and market.

To collect the detail information about the socio-economic conditions of fishermen, several parameters were used like age groups, education level, earners dependent ration etc.

\section{Results and Discussion}

\subsection{Analysis of fish biodiversity}

There are about 27 species of fish fauna found in the Belaibeel under 11 families, among them 23 species were indigenous and 4 species were exotic (Table 1). Some of them are common, less common and vulnerable. Among them the major dominant species are Bata (Labeo bata), Shingi (Heteropeneustes fossilis), Tengra (Mystus tengra), Chanda (Chanda nama), Kakila (Xenentodon cancila), Bele (Glossogobius giuris), Rui (Labeo rohita), Common carp (Cyprinus carpio), Mola (Amblypharyngodon mola), Katol (Catla catla), Taki (Channa punctatus),Tilapia (Oreochromis mossumbicus), Gachua (Channa orientalis), Magur (Clarius batrachus), Deshisharputi (Puntius sarana), Boal (Wallago attu), and Pangus (Pangasius pangasius) were found during the study period. The exotic fish species were Common carp (Cyprinus carpio), Nilotica (Oreochromis niloticus), Tilapia (O. mossambicus) and Pangus (Pangasius pangasius). A total 7 threatened fish species were recorded according to IUCN (2003) redlist of Bangladesh which is concurred with some other studies (Joadder, 2008b; Imteazzaman and Galib, 2013).

\subsection{Analysis of different fish groups}

Fish groups that have been found are Cat fish, Carp, Snakehead, Perch-like, Molacarpet, Barb, Featherback, Beel shad, Elongate glass perchlet and Freshwater garfish. Among them 8 species were Catfish (30\%), 5 species are found under Carp (19\%), 4 species were Snakehead (15\%), 3 species under Perch-like (10\%), 2 species were Molacarpet (7\%), 1 species under Barb (4\%), Featherback (4\%), Beelshad (4\%), Freshwater Garfish (4\%) and Elongate glass perchlet (4\%, Table 1 and Figure 2). This result is similar to other earlier studies (Rahman, 2000).

\subsection{Status of threatened fish species in the Belaibeel}

IUCN (2003) declared 54 fish species are threatened. Seven threatened fish species were found in the Belaibeel during the study period. Among them 5 species (Puntius sarana, Pangasius pangasius, L. bata, Chanda nama, Channa orientalis) were found to be available and 2 species (Notopterus notopterus, Channa marulius) rarely available. 
3.4. Socio-economic condition of the fishermen in the Belai beel

A total of forty fishermen living at Jelepara were interviewed from various places like house, fishing place, market, and field etc. Wide ranges of indicator were collected in various aspects of socio-economic characteristics.

\subsection{Analysis of age group}

According to Figure 3, 20\%, 50\%, 18\%, 10\%, 2\%, 0\% of fishermen were belonged to age group of 15-30, 31$40,41-50,51-60,61-70$ and 71-100 years respectively. Result showed that the highest number of fishermen were in between 31-40 age group indicating below middle age group was the dominant in fishing. This result is similar to the other regional studies (Kostori, 2012; Joadder, 2008a).

\subsection{Educational status of the fishermen}

The environment of education in the study area was not good enough. In the study area it was found that $15 \%$ of the fishermen passed class V, about $30 \%$ fishermen can sign only and $45 \%$ were illiterate (Figure 4). The present study was similar with Hossain et al. (2016), Asif et al. (2016).

\subsection{School going and dropout children of fishermen}

From the study, it was found that the number of school going children was 2 per house. It was observed that $54 \%$ were school dropout boy and $46 \%$ were girl. Due to illiteracy, unconsciousness, economic problem, income generating activities, social and other problems, the children of fishermen dropped out from the school (Figure 5).

Table 1. Biodiversity status of available fish species in the Belai beel over the study period.

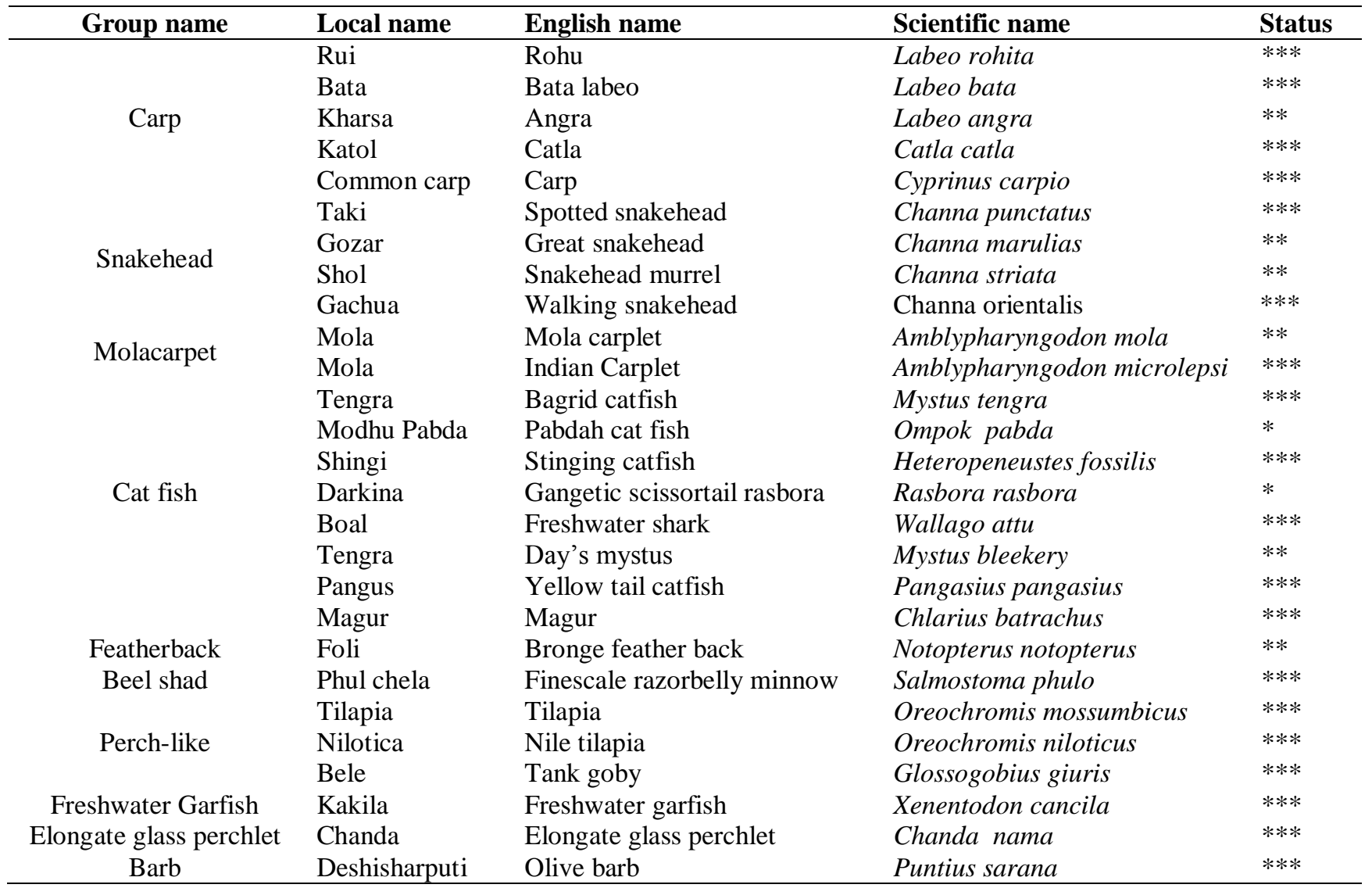

[***available fish species, ** less available fish species, and * vulnerable fish species.] 
Table 2. Earner-dependent ratio.

\begin{tabular}{llll}
\hline \multirow{2}{*}{ Family member } & \multicolumn{2}{c}{ Total Family number $(\mathbf{n}=\mathbf{4 0})$} & \multirow{2}{*}{ Ratio (Earner : Dependent) } \\
\cline { 2 - 3 } $1: 2.3$ \\
\cline { 2 - 3 } Total earners & No. & Percentage $(\boldsymbol{\%})$ & \\
Total dependents & 154 & $30 \%$ & \\
Total family members & 220 & $100 \%$ & \\
\hline
\end{tabular}

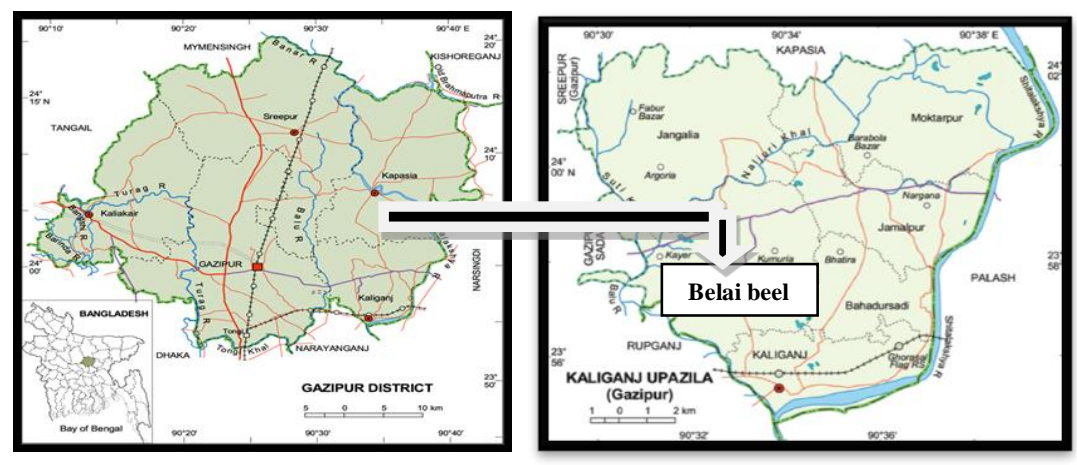

Figure 1. Study sites of Belai beel in Gazipur district.

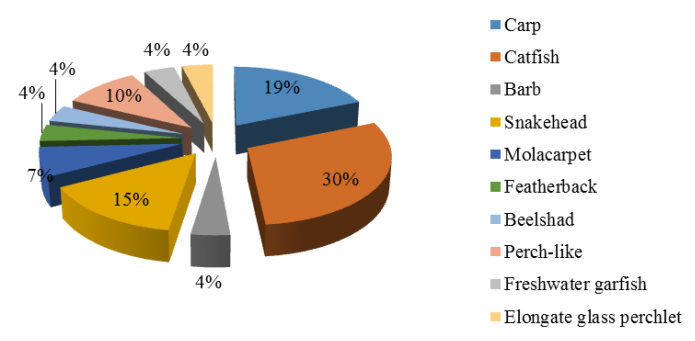

Figure 2. Percentage of different fish groups.

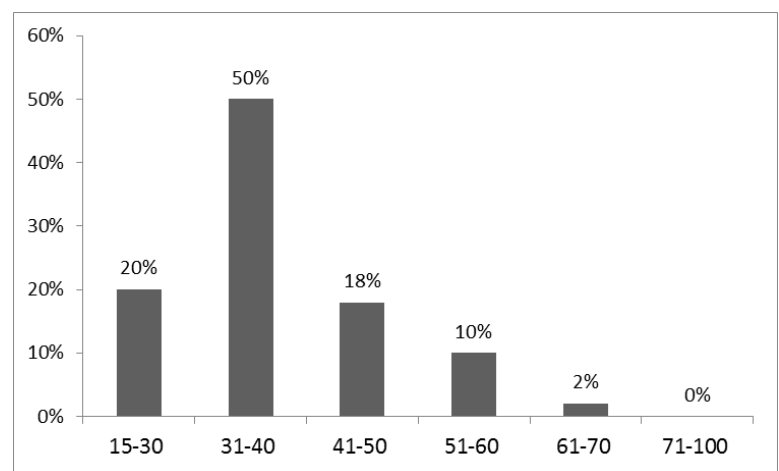

Figure 3. Age group distribution of fishermen of the Belai beel.

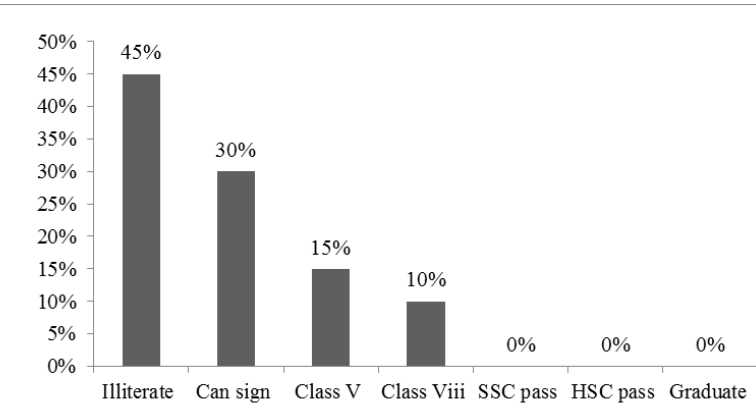

Figure 4. Educational status of the studied fishermen of the Belai beel. 




Figure 5. Reasons for school dropout children of the studied fishermen of the Belai beel.

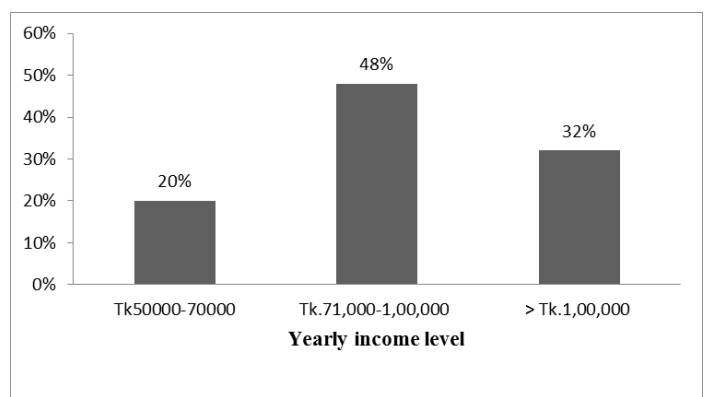

Figure 6. Yearly income status of the fishermen of the Belai beel.

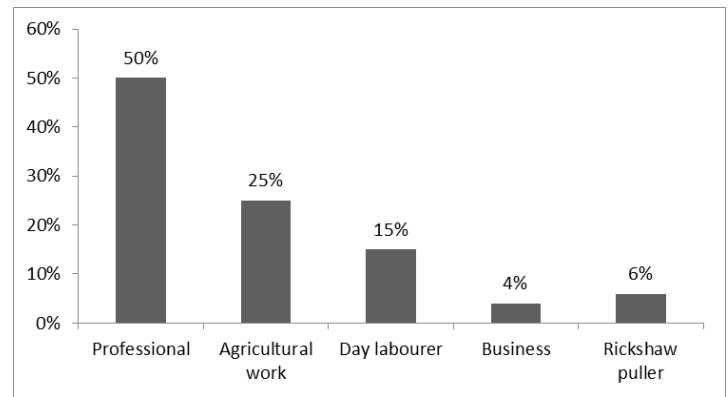

Figure7. Occupational status of fishermen of the study area.

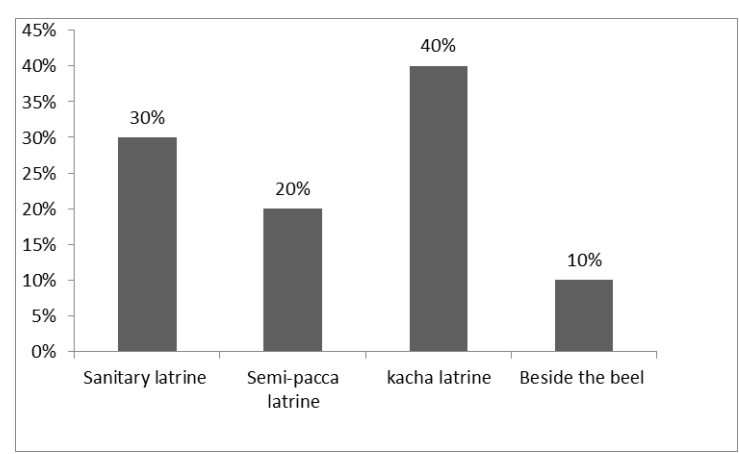

Figure 8. The sanitation status of the fishermen of the Belai beel.

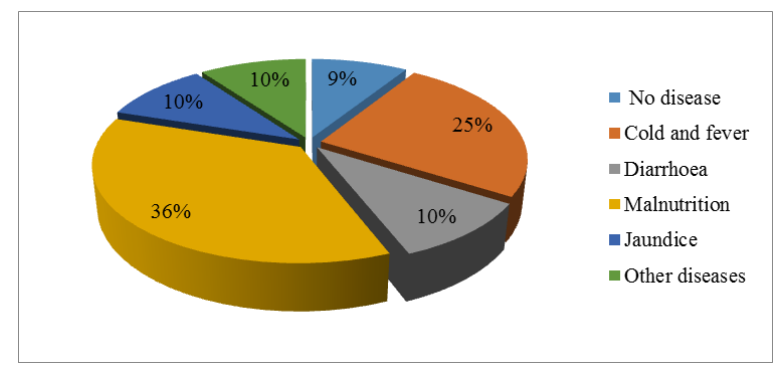

Figure 9. The diseases of the fishermen of the study area. 


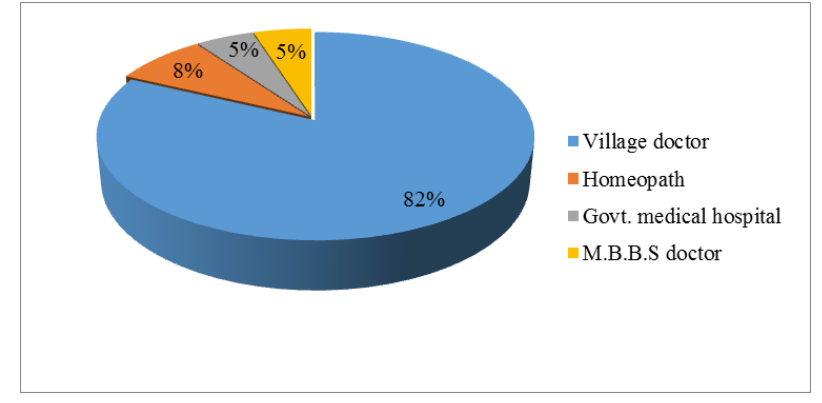

Figure 10. The nature of treatment taken by the fishermen.

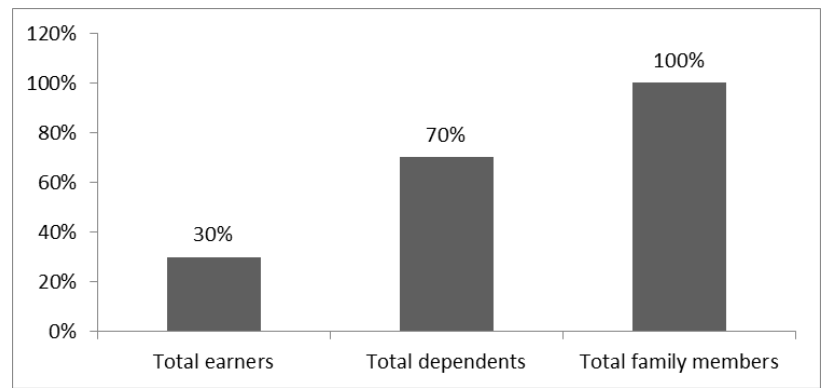

Figure 11. Earner-dependent profile of fishermen.

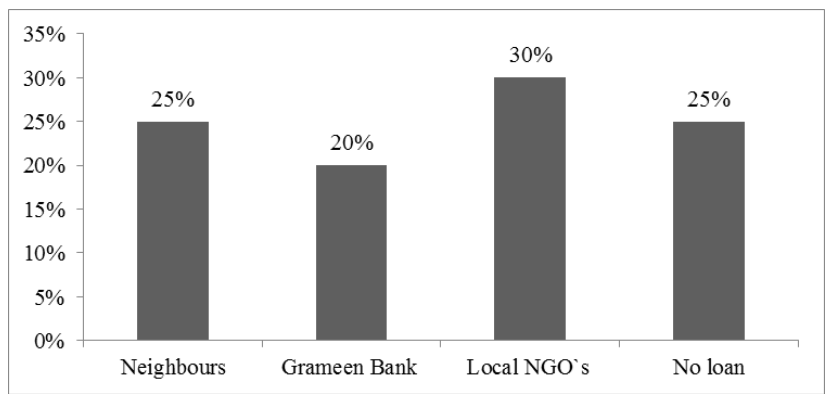

Figure 12. The credit system of the fishermen.

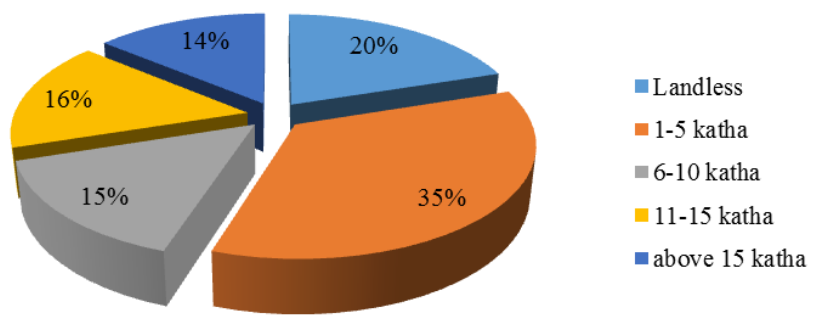

Figure 13. The land properties of fishermen.

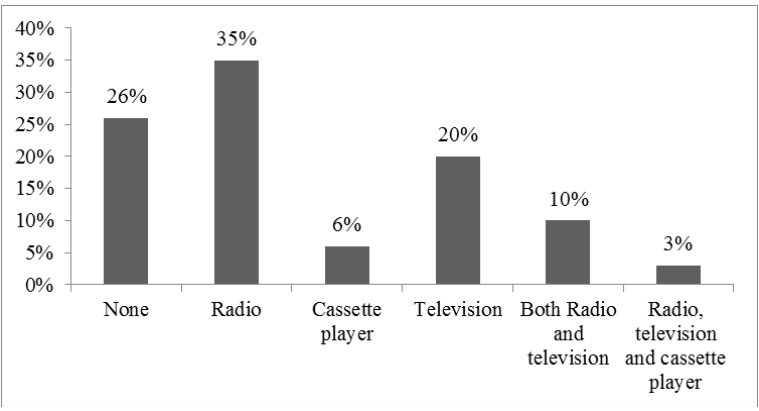

Figure 14. The recreational accessories of the fishermen. 
3.8. Income and living standard

The incomes of the fishermen were not so good. The only source of income of fishermen is selling fish. From the interviews, it was found that the highest income of the fishermen from selling fish was Tk. 350/day and the lowest income Tk. 300/day. Moreover, every year many people are getting involved in fishing as a seasonal or part time occupation. As a result, fishing pressure is continuously increasing in this beel. The study showed that $20 \%$ fishermen's yearly income was found to be Tk. 50000-70000, 48\% fishermen's yearly income was between Tk.71,000-1,00,000 and 32\% fishermen's yearly income was found > Tk.1,00,000 annually (Figure 6). The present study supports the previous studies of Alam (2005) and Dev (2011).

\subsection{Occupational status of the fisherman}

Among the subsistence fishermen $25 \%$ were engaged to agricultural work, $15 \%$ were day labourer, $4 \%$ were engaged in business, $6 \%$ were rickshaw puller. It was found that $50 \%$ fishermen were professional, $50 \%$ were part time fishermen (Figure 7). This result is similar to the other authors Bhaumik and Saha (1994).

\subsection{Sanitation}

In the study area $30 \%$ fishermen had sanitary latrine for defecation, $20 \%$ used semi-pacca latrine and $40 \%$ used kacha latrine. However, $10 \%$ fishermen do not have any latrine and they defecated beside the bank of the beel and agricultural land (Figure 8).

\subsection{Disease and treatment}

In the study area, among 40 fishermen, 3(9\%) did not suffers from any type of disease for the last six months. However, 10(25\%) suffered from cold and fever, 4(10\%) suffered from diarrhoea, $15(36 \%)$ suffered from malnutrition, 4(10\%) suffered from jaundice, 4(10\%) suffered from other diseases during the study period (Figure 9).

\subsection{Nature of disease treatment of the fishermen}

During the survey period of the 40 respondents, 33(82\%) fishermen went to village doctor for getting their treatment, $3(8 \%)$ took homeopath treatment, $2(5 \%)$ went to Govt. medical hospital and $2(5 \%)$ received treatment from local private practitioner having M.B.B.S (Bachelor of Medicine and Bachelor of Surgery) (Figure 10).

\subsection{Earners-Dependent ratio and credit operation}

The earning- depending ratio of the fishermen household is 1:2.3 (Table 2 and Figure 11). In the study area it was found that $25 \%$ fishermen borrowed money from the neighbours. $20 \%$ borrowed money from Grameen Bank by giving mortgage either land or household properties, $30 \%$ took loan from local NGO`s (ASA, BRAC etc.) and $25 \%$ did not take any loan (Figure 12).

\subsection{Landed properties and recreational accessories of the fishermen}

Of the total 40 fishermen $20 \%$ was landless, 35\% having land between 1-5 katha, 15\% having land between 610 katha, 16\% having land between 11-15 katha, 14\% having land above 15 katha (Figure 13). The fishermen and their children usually enjoy various types of traditional games and sports like Kabadi, Boat race etc. Besides some of the fishermen have various modern electronic and non-electronic accessories for their recreation. Among 40 fishermen some of the fishermen have various modern electronic and non-electronic accessories for their recreation. $26 \%$ of the fishermen do not have any electronic accessories, while $35 \%$ have only Radio, $6 \%$ have cassette player, $20 \%$ have only television, $10 \%$ have both Radio and television, and 3\% have radio, television and cassette player (Figure 14).

\section{Conclusions}

Freshwater resources are invaluable components of the environment, ecology, resource potential and biodiversity in Bangladesh. They are integral part of the local ecosystem based cultures. The fish production from natural resources sharply depleted in recent years due to indiscriminate fishing. The present study revealed that the Belai beel has 27 fish species but the socioeconomic condition of the fisherman was not good.

Based on the present findings, the following recommendations can be made for overall enhancement of fish biodiversity in the Belai beel like as fish act should be implemented properly, stop the catching of fishes during breeding season and fishermen communities should be educated. 


\section{Conflict of interest}

None to declare.

\section{References}

Asif AA, MA Samad, MH Rahman, MA Farid, SM Yeasmin, BMS Rahman and A Nima, 2015. Socioeconomic condition of fish fry and fingerling traders in greater Jessore region. Int. J. Fish. Aquat. Stud., 2: 290-293.

Alam MJ, 2005. Socio- economic conditions of Haor fishermen, a field level study. BRAC University Journal, 2:57-63.

Bhaumik U and SK Saha, 1994. Perspectives on the socio-economic status of the fishermen Department of Fisheries, Ministry of Fisheries and Livestock, Bangladesh.

Dev BK, 2011. Co-management Participation, Livelihood, and Status among Fishers in Baikka Beel, Bangladesh. Rural livelihoods and protected landscapes: Co-management in the Wetlands and Forests of Bangladesh. USAID/Bangladesh. 66-84.

DoF (Department of Fisheries), 2015. "National Fish Week 2015 Compendium (In Bengali)". engaged in fishing in the estuaries of Sundarbans. Environmenental Ecology, 12:181-185.

FAO, 2009. National Aquaculture Sector Overview, Bangladesh. Rome. <http://www.fao.org/fishery/country sector/naso_Bangladesh. (09 November).

Hossain MZ, A Pal, MA Hasan, MS Parvej, N Nahar and AA Asif, 2016. Nutritional status and sociodemographic characteristics of the people of south-west coastal region in Bangladesh. Asian Australas. J. Biosci. Biotechnol., 1: 323-332.

Imteazzaman AM, Galib SM. 2013. Fish Fauna of Halti Beel, Bangladesh. International Journal of Current Research, 5:187-190.

IUCN Bangladesh. 2003. Bangladesher Biponno Bonnoprani (Red Book of Threatened Animals), IUCN- The world conservation Union, XIV, 294.

Joadder MAR. 2008b. Ecology of Kumari Beel (Rajshahi). Northern part of Bangladesh. $3^{\text {rd }}$ Biennial Fisheries Conference \& Research Fair 2008, BFRI. 94.

Joadder, AR. 2008a. Socio-economic Condition of Fishermen of the "Mail Beel" under mohanpur Upazila of Rajshahi District in Bangladesh in Bangladesh. Research Journal of Biological Science, 3: 1178-1180.

Kostori MFA. 2012. Socio-economic Condition of Fishermen of the Chalan Beel under Tarash thana of Sirajganj District in Bangladesh. Bangladesh Research publications Journal, 6: 393-402.

Rahman AKA. 2005. Freshwater Fishes of Bangladesh, 2 nd edition. Zoological Society of Bangladesh, Dhaka, Bangladesh. 394.

Rahman MM. 2000. Comparison of benthic fauna of two beels of Netrokona district under different management conditions. M.S. Thesis. Department of Aquaculture, Bangladesh Agricultural University, Mymensingh. 